\title{
Elevation of serum adiponectin in mildly decreased glomerular filtration rate
}

\author{
Apinya Mahima ${ }^{1,2}$, Sudawadee Kongkhum ${ }^{3}$, Narisa Kengtong Bordeerat ${ }^{3}$, Somsak Fongsupa ${ }^{3}$, \\ Thaval Rerksngarm³, Pilaiwan Siripurkpong ${ }^{3, *}$
}

Abstract

Background: Adiponectin secreted by adipocytes plays a key role in insulin sensitivity, anti-inflammation, and antiatherosclerosis. It is involved in several conditions including obesity, type 2 diabetes mellitus, cardiovascular disease, and chronic kidney disease (CKD). Glomerular filtration rate is monitored to indicate the kidney function and $\mathrm{CKD}$ progression.

Objective: To assess the serum adiponectin levels in individuals with normal and mildly decreased glomerular filtration rate, analyze the association of serum adiponectin with various physical and biological parameters, and test whether serum adiponectin is the risk factor of mildly decreased glomerular filtration rate.

Methods: This cross-sectional study was conducted in 172 individuals with 35-60 years of age. Serum samples were collected and divided into two groups, based on estimated glomerular filtration rate (eGFR): 90 with normal eGFR (G1, eGFR $\left.\geq 90 \mathrm{~mL} / \mathrm{min} / 1.73 \mathrm{~m}^{2}\right)$ and 82 with mildly decreased eGFR $\left(\mathrm{G} 2, \mathrm{eGFR}=60-89 \mathrm{~mL} / \mathrm{min} / 1.73 \mathrm{~m}^{2}\right)$. Anthropometric data were recorded. Serum adiponectin was measured by enzyme-linked immunosorbent assay.

Results: Serum adiponectin levels were significantly increased in individuals with mildly decreased eGFR (G2), compared to $\mathrm{G} 1(8.23 \pm 3.26 \mu \mathrm{g} / \mathrm{mL}$ and $6.57 \pm 3.24 \mu \mathrm{g} / \mathrm{mL}$, respectively; $P=0.001)$. Serum adiponectin was positively associated with age and high-density lipoprotein cholesterol but negatively associated with weight, body mass index, triglyceride, and waist and hip circumferences. Univariate analysis showed that serum adiponectin was significantly correlated with mildly decreased eGFR; however, when adjusting for confounding factors, there were no correlations. Furthermore, multivariate regression analysis showed that individuals at the age of 46-55 years $(4.0 ; 95 \%$ CI: $1.9-8.3)$ and $>55$ years $(11.4 ; 95 \%$ CI: 3.7-35.5) were significantly correlated with mildly decreased eGFR.

Conclusions: Serum adiponectin was significantly elevated in individuals with mildly decreased eGFR and may be a modulation factor, but was not an independent risk factor for mildly kidney damage. Further study is needed to clarify its potential benefits as monitoring biomarker for CKD progression.

Keywords: adiponectin; chronic; glomerular filtration rate; renal insufficiency

*Correspondence to: Pilaiwan Siripurkpong, Department of Medical Technology, Faculty of Allied Health Sciences, Thammasat University, Pathum Thani 12120, Thailand, e-mail: pilaiwan.s@allied.tu.ac.th

'Graduate program in Medical Technology, Faculty of Allied Health Sciences, Thammasat University, Pathum Thani 12120, Thailand

2Department of Medical Technology Laboratory, Ratchaburi Hospital, Ratchaburi 70000, Thailand

${ }^{3}$ Department of Medical Technology, Faculty of Allied Health Sciences, Thammasat University, Pathum Thani 12120, Thailand

¿ Open Access. ๑ 2018 Apinya Mahima et al., published by Sciendo. (c) Br-Nc-ND This work is licensed under the Creative

Commons Attribution NonCommercial-NoDerivatives 4.0 License. 
Adiponectin, also referred to as GBP28, apM1, AdipoQ, and Acrp30, is a $30-\mathrm{kDa}$ polypeptide secreted exclusively by adipocyte that has functions in the regulation of glucose and lipid metabolisms [1]. Previous studies revealed the roles of adiponectin as an anti-inflammatory, anti-diabetic, and vascular protective adipokine $[2,3]$. Reduction of serum adiponectin is associated with obesity [4-6], insulin resistance [7, 8], and cardiovascular diseases $[9,10]$. In addition, serum adiponectin is described as an independent (inverse) risk of cardiovascular events and mortality among individuals with endstage kidney disease [11]. Inversely, reports have shown that serum adiponectin increases in chronic kidney disease (CKD) [12-14], especially in individuals with end-stage kidney disease [15]. When the kidney is damaged or impaired, the glomerular filtration rate (GFR) decreases, resulting in an accumulation of adiponectin in blood circulation [11].

CKD is a noncommunicable disease, which is the global epidemic with increasing prevalence [16]. CKD is defined as abnormalities of kidney structure or function for $>3$ months [17], which may be detected by decreases in GFR and/or the presence of proteinuria. As a result, CKD individuals are classified into five stages; stage 1, normal GFR (eGFR $\geq 90 \mathrm{~mL} / \mathrm{min} / 1.73 \mathrm{~m}^{2}$ ); stage 2, mild kidney damage $\left(\mathrm{eGFR}=60-89 \mathrm{~mL} / \mathrm{min} / 1.73 \mathrm{~m}^{2}\right)$; stage 3 , moderate kidney damage $\left(\mathrm{eGFR}=30-59 \mathrm{~mL} / \mathrm{min} / 1.73 \mathrm{~m}^{2}\right)$; stage 4, severe kidney damage $\left(\mathrm{eGFR}=15-29 \mathrm{~mL} / \mathrm{min} / 1.73 \mathrm{~m}^{2}\right)$; and stage 5, kidney failure (eGFR $<15 \mathrm{~mL} / \mathrm{min} /$ $1.73 \mathrm{~m}^{2}$ ); Moderate-to-severe kidney damage (eGFR $<60 \mathrm{~mL} / \mathrm{min} / 1.73 \mathrm{~m}^{2}$ ) is associated with albuminuria $[18,19]$. The albuminuria categories in CKD are stratified according to urinary albumin excretion (UAE; $\mathrm{mg} / 24 \mathrm{~h}$ ) and urine albumin-to-creatinine ratio (UACR; $\mathrm{mg} / \mathrm{g})<30,30-300$, or $>300$, which fits well with the classification of normal to mildly increased, moderately, and severely increased albuminuria, respectively [20]. Stages 1 and 2 are described as the early stage of CKD and usually have no signs and symptoms. However, it can be diagnosed by slightly elevated serum creatinine and the presence of normal to mildly increased albuminuria, caused by a decline in glomerular and tubular functions [21].

As serum adiponectin markedly increases in end-stage kidney disease, it may reflect in the early stage of CKD. Therefore, this study aimed to assess levels of serum adiponectin in mildly decreased GFR, examine the relationship between serum adiponectin and other parameters, and evaluate serum adiponectin as the risk factor of mildly decreased GFR.

\section{Materials and methods}

\section{Study population}

This cross-sectional study included 172 volunteers ( 36 males and 136 females) at the age of 35-60 years with no history of type 1 and type 2 diabetes, cardiovascular disease, CKD with eGFR $<60 \mathrm{~mL} / \mathrm{min} / 1.73 \mathrm{~m}^{2}$, UACR $>300 \mathrm{mg} / \mathrm{g}$, use of drugs that affect kidney and liver functions, such as analgesic, antipyretic, and antibiotic drugs. Based on estimated glomerular filtration rate (eGFR) defined by the Kidney Disease: Improving Global Outcomes (KDIGO: 2012) [22], they were classified into two groups: 82 cases with mildly decreased eGFR $\left(\mathrm{G} 2\right.$, eGFR $\left.=60-89 \mathrm{~mL} / \mathrm{min} / 1.73 \mathrm{~m}^{2}\right)$ and 90 with normal eGFR (G1, eGFR $\geq 90 \mathrm{~mL} / \mathrm{min} / 1.739 \mathrm{~m}^{2}$ ). Anthropometric data (gender, age, weight, blood pressure, and waist and hip circumferences) were collected. This study protocol was approved by the Human Research Ethics Committee at Thammasat University (certificate of approval No. 119/2559) and informed consent was obtained from all participants.

\section{Sample collection and biochemical analysis}

Overnight ( $8-12 \mathrm{~h}$ ) fasting blood and urine were collected and placed immediately on ice. Plasma and serum samples were prepared by centrifugation at $1000 \times \mathrm{g}$ for $5-10 \mathrm{~min}$ and kept at $-70^{\circ} \mathrm{C}$ until further analysis. Fasting plasma glucose (FPG), total cholesterol, triglyceride, high-density lipoprotein cholesterol (HDL-cholesterol), low-density lipoprotein cholesterol (LDLcholesterol) and creatinine were measured using the automated blood analyzer (Dxc800; Beckman Coulter). Calculation of eGFR was done using the Chronic Kidney Disease Epidemiology Collaboration (CKD-EPI) equation, 2012 [23, 24]. Urine albumin was measured by the immunoturbidimetric assay (manufacturer). UACR was calculated using urine albumin in milligram $(\mathrm{mg})$ and urine creatinine in gram $(\mathrm{g})$. Serum adiponectin was analyzed using the sandwich enzyme-linked immunosorbent assay kit (DY1065, R\&D system), which was verified. The percent recovery was $97.36 \%$ and the inter-assay and intra-assay coefficients of variation were $6.93 \%$ and $7.31 \%$, respectively.

\section{Statistical analyses}

Data were reported as means \pm standard deviation (SD) and analyzed using SPSS software version 23; IBM USA. Data comparisons for continuous variables between two groups were performed using the Mann-Whiney U test. The KruskalWallis tests were used to analyze the statistical difference 
Table 1. Anthropometric characteristics and biochemical variables of the mildly decreased eGFR (G2) and the normal eGFR (G1)

\begin{tabular}{|c|c|c|c|}
\hline Variables & $\begin{array}{l}\text { Normal eGFR (G1) } \\
\quad(n=90)\end{array}$ & $\begin{array}{l}\text { Mildly decreased eGFR (G2) } \\
\qquad(\mathrm{n}=82)\end{array}$ & $P$ \\
\hline \multicolumn{4}{|l|}{ Sex } \\
\hline Male, n (\%) & $14(16)$ & $22(27)$ & \\
\hline Female, n (\%) & $76(84)$ & $60(73)$ & $0.069^{\mathrm{a}}$ \\
\hline Age (years) & $43.52 \pm 5.92$ & $50.17 \pm 6.42$ & $<0.001^{* b}$ \\
\hline Weight (kg) & $63.53 \pm 12.36$ & $62.24 \pm 9.99$ & $0.760^{\mathrm{b}}$ \\
\hline Body mass index $\left(\mathrm{kg} / \mathrm{m}^{2}\right)$ & $24.697 \pm 3.87$ & $24.09 \pm 3.10$ & $0.624^{b}$ \\
\hline Waist $(\mathrm{cm})$ & $82.56 \pm 10.14$ & $83.72 \pm 8.35$ & $0.278^{b}$ \\
\hline $\mathrm{Hip}(\mathrm{cm})$ & $98.94 \pm 8.91$ & $97.54 \pm 7.50$ & $0.331^{\mathrm{b}}$ \\
\hline Waist-to-hip ratio & $0.84 \pm 0.07$ & $0.86 \pm 0.06$ & $0.062^{b}$ \\
\hline $\mathrm{DBP}(\mathrm{mmHg})$ & $75.89 \pm 9.33$ & $80.20 \pm 10.34$ & $<0.001^{* b}$ \\
\hline $\mathrm{SBP}(\mathrm{mmHg})$ & $116.28 \pm 12.46$ & $124.32 \pm 13.25$ & $<0.001^{* b}$ \\
\hline Body adipose & $30.98 \pm 4.88$ & $30.20 \pm 4.96$ & $0.274^{b}$ \\
\hline Creatinine (mg/dL) & $0.70 \pm 0.11$ & $0.92 \pm 0.14$ & $<0.001^{* b}$ \\
\hline eGFR & $105.02 \pm 8.33$ & $80.20 \pm 6.98$ & $<0.001^{* b}$ \\
\hline UACR (mg/g) & $6.71 \pm 4.27$ & $8.13 \pm 9.39$ & $0.582^{\mathrm{b}}$ \\
\hline $\mathrm{FPG}(\mathrm{mg} / \mathrm{dL})$ & $88.44 \pm 6.56$ & $88.91 \pm 6.97$ & $0.630^{\mathrm{b}}$ \\
\hline Cholesterol (mg/dL) & $225.56 \pm 50.23$ & $229.27 \pm 45.45$ & $0.480^{\mathrm{b}}$ \\
\hline Triglyceride (mg/dL) & $113.42 \pm 54.58$ & $125.43 \pm 69.30$ & $0.321^{\mathrm{b}}$ \\
\hline $\mathrm{HDL}-\mathrm{C}(\mathrm{mg} / \mathrm{dL})$ & $54.29 \pm 14.54$ & $60.61 \pm 15.16$ & $0.012^{* b}$ \\
\hline $\mathrm{LDL}-\mathrm{C}(\mathrm{mg} / \mathrm{dL})$ & $144.36 \pm 38.66$ & $143.45 \pm 40.13$ & $0.800^{\mathrm{b}}$ \\
\hline Serum adiponectin $(\mathrm{mg} / \mathrm{mL})$ & $6.57 \pm 3.24$ & $8.23 \pm 3.26$ & $<0.001^{* b}$ \\
\hline
\end{tabular}

DBP, diastolic blood pressure; SBP, systolic blood pressure; eGFR, estimated glomerular filtration rate; UACR, urine albumin-to-creatinine ratio; FPG, Fasting plasma glucose; HDL-C, high-density lipoprotein cholesterol; LDL-C, low-density lipoprotein cholesterol.

Categorical variables are shown as percentage (\%).

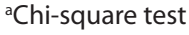

${ }^{b}$ Mann-Whitney $\mathrm{U}$ test

${ }^{*} P<0.05$ was considered significant.

between the three groups $(P<0.05)$. When significance was observed, a post-hoc test was used for pairwise analyses $(P<0.05)$. Spearman's rank correlation coefficients were used to examine the correlation between serum adiponectin and other parameters. Multiple linear regression analysis was used to evaluate the effects of other confounding factors for serum adiponectin. Univariate and multivariate analyses were conducted using a logistic regression with $95 \%$ confidence interval. $P<0.05$ was considered a statistical significance. Receiver operating characteristic (ROC) curve showed the plot between specificity and sensitivity of serum adiponectin levels at a cutoff point as a predictor for mildly decreased eGFR.

\section{Results}

\section{Baseline characteristics}

Anthropometric data and biochemical variables of individuals with normal (G1, control, $\mathrm{n}=90)$ and mildly decreased eGFR
$(\mathrm{G} 2, \mathrm{n}=82)$ are shown in Table 1. Ages, blood pressure, serum creatinine, HDL-cholesterol, and serum adiponectin were significantly higher in the G2 group than the G1 control. Waist circumference, waist per hip ratio (WHR), body adiposity index (BAI), triglyceride, and UACR slightly increased in the G2 group; however, there was no significant difference between the G2 and G1 groups. Both G1 and G2 groups have similar weight, body mass index (BMI), FPG, total cholesterol, and LDL-cholesterol.

\section{Serum adiponectin in mildly decreased eGFR}

Serum adiponectin was higher in individuals with mildly decreased eGFR $(\mathrm{G} 2,8.23 \pm 3.26 \mathrm{mg} / \mathrm{mL})$ than in the $\mathrm{G} 1$ control $(6.57 \pm 3.24 \mathrm{mg} / \mathrm{mL})$ with the $P$ value of 0.001 (Figure 1). In the G2 group, females had higher serum adiponectin than males ( $8.92 \pm 3.41$ and $6.28 \pm 1.76 \mathrm{mg} / \mathrm{mL}$, respectively) with the $P$ value of 0.002 . However, the G1 control showed no significant differences in serum adiponectin between males and 


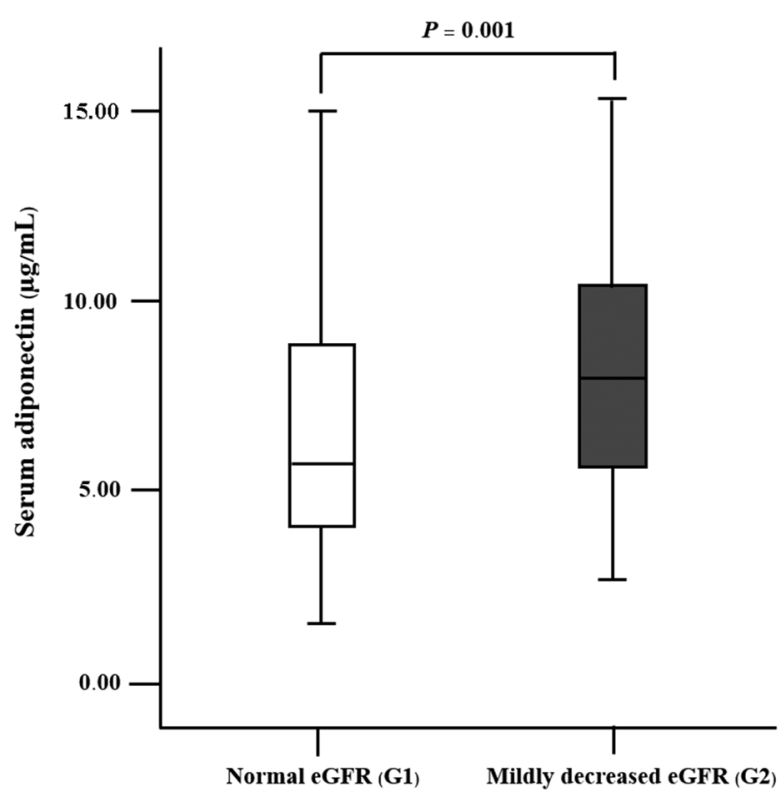

Figure 1. Comparison of the serum adiponectin between the mildly decreased eGFR (G2) and the control with normal eGFR (G1). $P$ : Mann-Whiney $U$ test

females $(5.39 \pm 2.99$ and $6.79 \pm 3.26 \mathrm{mg} / \mathrm{mL}$, respectively $)$ with the $P$ values of 0.101 (Figure 2).

When data were classified based on Asian BMI criteria [25] as normal weight $\left(18.5-22.9 \mathrm{~kg} / \mathrm{m}^{2}\right)$, overweight $(23.0$ $\left.24.9 \mathrm{~kg} / \mathrm{m}^{2}\right)$, and obesity $\left(\geq 25.0 \mathrm{~kg} / \mathrm{m}^{2}\right)$, it was shown that serum adiponectin in each group was higher in the G2 than the G1 control. However, the significant difference $(P<0.05)$ was found only in G1 control. Serum adiponectin levels were significantly lower in the obesity than the overweight and the normal weight with $P$ value of 0.025 and 0.034 , respectively (Figure 3).

The Spearman's rank correlation coefficient test revealed the correlations between serum adiponectin and anthropometric parameters and biochemical variables (Table 2). Serum adiponectin was significantly correlated with ages $(r=0.355)$, gender $(r=0.196)$, weight $(r=-0.306)$, BMI $(r=-0.217)$, waist circumference $(r=-0.236)$, hip circumference $(r=-0.256)$, eGFR $(r=-0.257)$, triglyceride $(r=-0.204)$, and HDL-cholesterol $(r=0.444)$, but not significantly correlated with WHR, BAI, creatinine, UACR, FPG, total cholesterol, LDL-cholesterol, and blood pressure. Multiple linear regression analysis setting serum adiponectin as a dependent factor showed that ages, HDL-cholesterol, and LDL-cholesterol were independently and significantly associated with serum adiponectin (Table 3 ).

The univariate and multivariate logistic regression analyses for a predictive index of mildly decreased eGFR

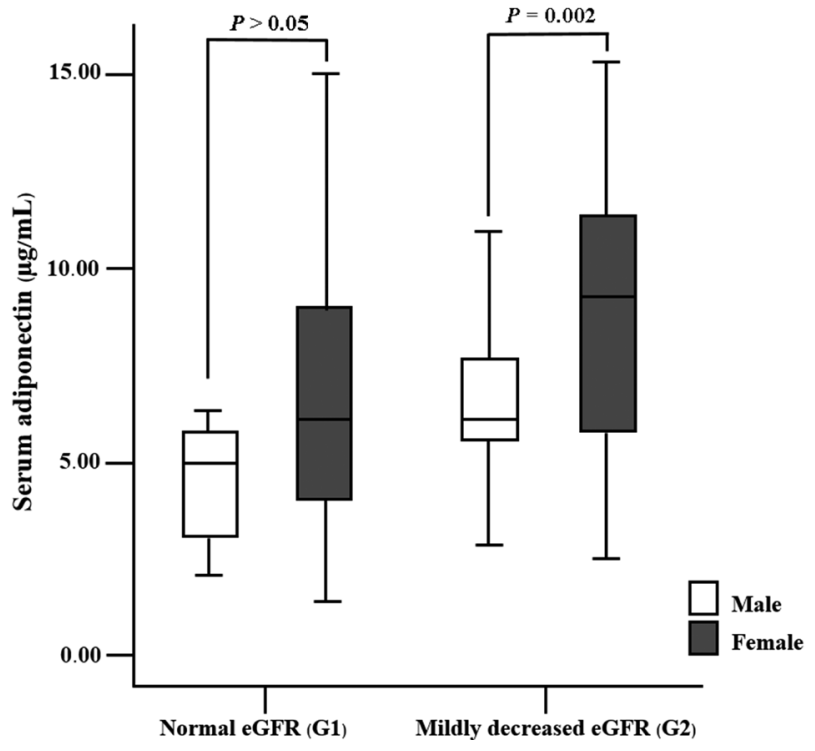

Figure 2. Comparison of serum adiponectin in male (open bars) and female (solid bars) in the mildly decreased eGFR (G2) and the control with normal eGFR (G1). P: Mann-Whiney U test

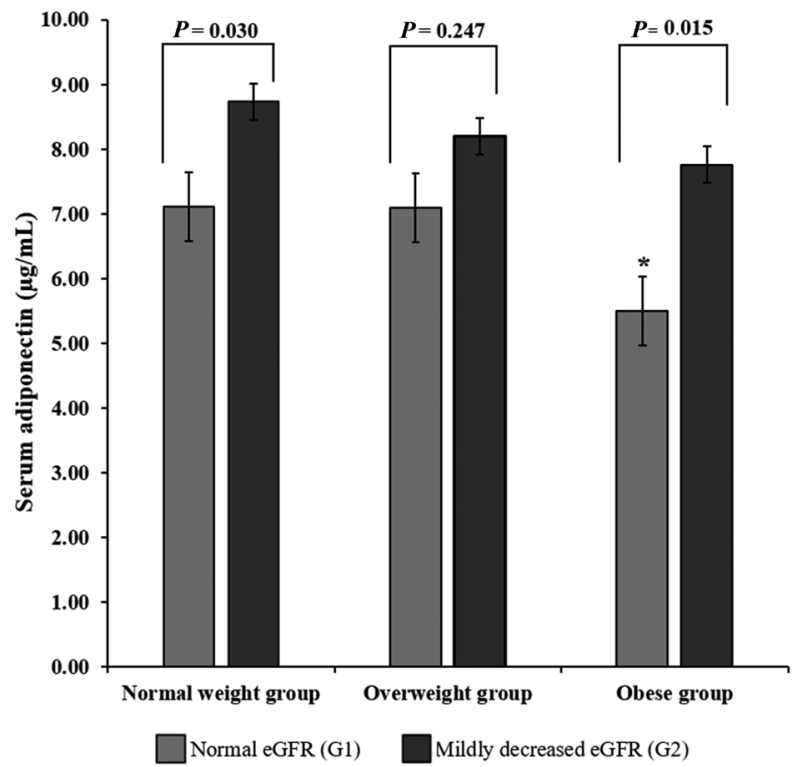

Figure 3. Comparison of serum adiponectin between the normal eGFR (gray bar) and the mildly decreased eGFR (black bar) among normal weight, overweight, and obesity based on Asian BMI. The Kruskal-Wallis test followed by a post-hoc test was used to determine the differences between three independent groups and all pairwise comparisons. $\left({ }^{*} P<0.05\right.$ vs normal weight group and obese group and overweight group and obese group)

are summarized in Table 4. Univariate regression showed that individuals older than 46 years, hypertension (systolic blood pressure $[\mathrm{SBP}] \geq 130 \mathrm{mmHg}$, diastolic blood pressure 
Table 2. Bivariate spearman's rank correlation coefficients between serum adiponectin with anthropometric characteristics and biochemical variables

\begin{tabular}{lcc}
\hline & \multicolumn{2}{c}{ Serum adiponectin $(\mu \mathbf{g} / \mathrm{mL})$} \\
\cline { 2 - 3 } Variables & $\boldsymbol{r}$ & $\boldsymbol{P}$ \\
\hline Age (year) & $\mathbf{0 . 3 5 5}$ & $<\mathbf{0 . 0 0 1 *}$ \\
Weight $(\mathrm{kg})$ & $-\mathbf{0 . 3 0 6}$ & $<\mathbf{0 . 0 0 1 *}$ \\
Body mass index $\left(\mathrm{kg} / \mathrm{m}^{2}\right)$ & $-\mathbf{0 . 2 1 7}$ & $\mathbf{0 . 0 0 4 ^ { * }}$ \\
Waist $(\mathrm{cm})$ & $-\mathbf{0 . 2 3 6}$ & $\mathbf{0 . 0 0 2 *}$ \\
Hip $(\mathrm{cm})$ & $-\mathbf{0 . 2 5 6}$ & $\mathbf{0 . 0 0 1 *}$ \\
Waist-to-hip ratio & -0.105 & 0.168 \\
DBP $(\mathrm{mmHg})$ & -0.071 & 0.358 \\
SBP $(\mathrm{mmHg})$ & 0.004 & 0.963 \\
Body adiposity index & -0.068 & 0.379 \\
Creatinine $(\mathrm{mg} / \mathrm{dL})$ & -0.073 & 0.344 \\
eGFR & $-\mathbf{0 . 2 5 7}$ & $\mathbf{0 . 0 0 1 *}$ \\
UACR $(\mathrm{mg} / \mathrm{g})$ & 0.108 & 0.159 \\
FPG $(\mathrm{mg} / \mathrm{dL})$ & -0.005 & 0.947 \\
Cholesterol $(\mathrm{mg} / \mathrm{dL})$ & -0.056 & 0.469 \\
Triglyceride $(\mathrm{mg} / \mathrm{dL})$ & $-\mathbf{0 . 2 0 4}$ & $\mathbf{0 . 0 0 7 *}$ \\
HDL-C $(\mathrm{mg} / \mathrm{dL})$ & $\mathbf{0 . 4 4 4}$ & $<\mathbf{0 . 0 0 1 *}$ \\
LDL-C $(\mathrm{mg} / \mathrm{dL})$ & -0.082 & 0.283 \\
\hline
\end{tabular}

Spearman's rank correlation coefficients, ${ }^{*} P<0.05$ was considered significant.
$[\mathrm{DBP}] \geq 85 \mathrm{mmHg}$ ), and serum adiponectin (cutoff $=5.7 \mathrm{mg}$ / $\mathrm{mL}$ ) were significantly associated with the mildly decreased eGFR (G2). Multivariate regression analysis showed that individuals at the ages of 46-55 years $(4.0 ; 95 \% \mathrm{CI}: 1.9-8.3)$ and $>55$ years $(11.4$; 95\% CI: 3.7-33.5) were significantly correlated with the mildly decreased eGFR after adjusting for age, SBP, DBP, and serum adiponectin (Table 4). ROC curve analysis of serum adiponectin for detection of mildly decreased eGFR (G2) showed 70.7\% specificity and 50\% sensitivity at the cutoff value of $5.70 \mathrm{mg} / \mathrm{mL}$. The area under the ROC curve was 0.652 (95\% CI: $0.570-0.733, P=0.001)$.

\section{Discussion}

The present study revealed, for the first time, that serum adiponectin increased in individuals with mildly decreased eGFR (G2) compared to normal (G1) in all groups; normal weight, overweight, and obesity. This was consistent with previous studies showing that serum adiponectin levels increase in CKD patients [12-14]. The possible explanation was that inflammatory stimuli found in CKD induce adiponectin expression in renal tubular cells to trigger a feedback response [26], leading to increases in circulating adiponectin levels.

Table 3. Multiple linear regression with adiponectin as a dependent variable $(N=172)$

\begin{tabular}{|c|c|c|c|c|c|}
\hline \multirow{2}{*}{ Independent variables } & \multicolumn{2}{|c|}{ Unstandardized coefficients } & \multirow{2}{*}{$\begin{array}{c}\text { Standardized coefficients } \\
\text { Beta }\end{array}$} & \multirow{2}{*}{$\boldsymbol{t}$} & \multirow{2}{*}{$P<0.05$} \\
\hline & B & Std. Error & & & \\
\hline Constant & 22.190 & 36.021 & & 0.616 & 0.539 \\
\hline Age (year) & 0.117 & 0.052 & 0.244 & 2.248 & $0.026^{*}$ \\
\hline Weight (kg) & 0.244 & 0.247 & 0.822 & 0.989 & 0.324 \\
\hline BMI $\left(\mathrm{kg} / \mathrm{m}^{2}\right)$ & -0.595 & 0.643 & -0.627 & -0.926 & 0.356 \\
\hline Waist (cm) & -0.078 & 0.264 & -0.216 & -0.295 & 0.769 \\
\hline $\operatorname{Hip}(\mathrm{cm})$ & -0.094 & 0.343 & -0.233 & -0.275 & 0.784 \\
\hline Waist-to-hip ratio & 3.976 & 24.328 & 0.084 & 0.163 & 0.870 \\
\hline $\mathrm{DBP}(\mathrm{mmHg})$ & -0.050 & 0.032 & -0.150 & -1.534 & 0.127 \\
\hline $\mathrm{SBP}(\mathrm{mmHg})$ & 0.019 & 0.025 & 0.077 & 0.783 & 0.435 \\
\hline Body adiposity index & 0.182 & 0.485 & 0.268 & 0.375 & 0.708 \\
\hline Creatinine $(\mathrm{mg} / \mathrm{dL})$ & -1.451 & 4.985 & -0.073 & -0.291 & 0.771 \\
\hline eGFR & -0.030 & 0.053 & -0.129 & -0.562 & 0.575 \\
\hline $\mathrm{UACR}(\mathrm{mg} / \mathrm{g})$ & 0.021 & 0.031 & 0.045 & 0.664 & 0.508 \\
\hline FPG (mg/dL) & 0.054 & 0.035 & 0.108 & 1.554 & 0.122 \\
\hline Cholesterol (mg/dL) & 0.020 & 0.011 & 0.289 & 1.909 & 0.058 \\
\hline Triglyceride (mg/dL) & -0.006 & 0.005 & -0.103 & -1.152 & 0.251 \\
\hline $\mathrm{HDL}-\mathrm{C}(\mathrm{mg} / \mathrm{dL})$ & 0.053 & 0.020 & 0.241 & 2.651 & $0.009 *$ \\
\hline LDL-C (mg/dL) & -0.030 & 0.012 & -0.351 & -2.537 & $0.012 *$ \\
\hline \multicolumn{6}{|c|}{ Constant $=22.190 ; R=0.600 ; R^{2}=0.280 ; \mathrm{SE}_{\mathrm{est}}= \pm 2.82 ; F=4.494 ; P<0.05$} \\
\hline
\end{tabular}

Serum adiponectin $=22.190+0.117(\mathrm{Age})+0.053(\mathrm{HDL}-\mathrm{C})-0.030(\mathrm{LDL}-\mathrm{C})$. 
Table 4. Univariate and multivariate analyses of risk for mildly decreased eGFR

\begin{tabular}{|c|c|c|c|c|c|c|}
\hline Variables & $\begin{array}{l}\text { Case } \\
\text { N (\%) }\end{array}$ & $\begin{array}{l}\text { Control } \\
\text { N (\%) }\end{array}$ & $\begin{array}{c}\text { Crude OR } \\
(95 \% \mathrm{Cl})\end{array}$ & $P$ & $\begin{array}{c}\text { Adjusted OR } \\
(95 \% \mathrm{Cl})\end{array}$ & $P$ \\
\hline \multicolumn{7}{|l|}{ Sex } \\
\hline Male & $22(26.8)$ & $14(15.6)$ & 1 & & & \\
\hline Female & $60(73.2)$ & $76(84.4)$ & $0.5(0.2-1.1)$ & 0.072 & & \\
\hline \multicolumn{7}{|l|}{ Age (years) } \\
\hline $35-45$ & $20(24.4)$ & $60(66.7)$ & 1 & & 1 & \\
\hline $46-55$ & $38(46.3)$ & $25(27.8)$ & $4.5(2.2-9.3)$ & $<0.001^{*}$ & $4.0(1.9-8.3)$ & $<0.001^{*}$ \\
\hline$>55$ & $24(29.3)$ & $5(5.5)$ & $14.4(4.9-42.8)$ & $<0.001^{*}$ & $11.4(3.7-35.5)$ & $<0.001^{*}$ \\
\hline \multicolumn{7}{|l|}{ Body mass index $\left(\mathrm{kg} / \mathrm{m}^{2}\right)$} \\
\hline Normal & $30(36.6)$ & $30(33.3)$ & 1 & & & \\
\hline Overweight & 27 (37.9) & $30(33.3)$ & $0.9(0.4-1.9)$ & 0.776 & & \\
\hline Obese & $25(30.5)$ & $30(33.3)$ & $0.8(0.4-1.7)$ & 0.626 & & \\
\hline \multicolumn{7}{|l|}{ Waist-to-hip ratio } \\
\hline Male $\leq 0.90$, Female $\leq 0.85$ & $52(63.4)$ & $63(70.0)$ & 1 & & & \\
\hline Male $>0.90$, Female $>0.85$ & $30(36.6)$ & $27(30.0)$ & $1.3(0.7-2.5)$ & 0.360 & & \\
\hline \multicolumn{7}{|l|}{$\mathrm{SBP}(\mathrm{mmHg})$} \\
\hline$<130$ & $57(69.5)$ & $77(85.6)$ & 1 & & 1 & \\
\hline$\geq 130$ & $25(30.5)$ & $13(14.4)$ & $2.6(1.2-5.5)$ & $0.013^{*}$ & $1.2(0.4-3.4)$ & 0.689 \\
\hline \multicolumn{7}{|l|}{$\mathrm{DBP}(\mathrm{mmHg})$} \\
\hline$<85$ & $53(64.6)$ & $75(83.3)$ & 1 & & 1 & \\
\hline$\geq 85$ & $29(35.4)$ & $15(16.7)$ & $2.7(1.4-5.9)$ & $0.006^{*}$ & $2.2(0.8-5.5)$ & 0.112 \\
\hline \multicolumn{7}{|l|}{ Glucose (mg/dL) } \\
\hline$<100$ & $78(95.1)$ & $89(5.6)$ & 1 & & & \\
\hline$\geq 100$ & $4(4.9)$ & $1(1.1)$ & $4.5(0.5-41.7)$ & 0.179 & & \\
\hline \multicolumn{7}{|l|}{ Cholesterol (mg/dL) } \\
\hline$<200$ & $18(22.0)$ & $28(31.1)$ & 1 & & & \\
\hline$\geq 200$ & $64(78.0)$ & $62(68.9)$ & $1.6(0.8-3.2)$ & 0.177 & & \\
\hline \multicolumn{7}{|l|}{ Triglyceride (mg/dL) } \\
\hline$<150$ & $58(70.7)$ & $71(78.9)$ & 1 & & & \\
\hline$\geq 150$ & $24(29.3)$ & $19(21.1)$ & $1.5(0.8-3.1)$ & 0.219 & & \\
\hline \multicolumn{7}{|l|}{$\mathrm{HDL}-\mathrm{C}(\mathrm{mg} / \mathrm{dL})$} \\
\hline Male $\geq 40$, Female $\geq 50$ & $14(17.1)$ & $23(25.6)$ & 1 & & & \\
\hline Male $<40$, Female $<50$ & $68.6(82.9)$ & $67(74.4)$ & $1.6(0.8-3.5)$ & 0.179 & & \\
\hline \multicolumn{7}{|l|}{$\mathrm{LDL}-\mathrm{C}(\mathrm{mg} / \mathrm{dL})$} \\
\hline$<100$ & $11(12.6)$ & $9(10.0)$ & 1 & & & \\
\hline$\geq 100$ & $76(87.4)$ & $81(90.0)$ & $0.8(0.3-2.1)$ & 0.647 & & \\
\hline \multicolumn{7}{|l|}{ Serum adiponectin $(\mathrm{mg} / \mathrm{mL})$} \\
\hline$<5.70$ & $24(29.3)$ & $45(50.0)$ & 1 & & 1 & \\
\hline$\geq 5.70$ & $58(70.7)$ & $45(50.0)$ & $2.4(1.3-4.5)$ & $0.006^{*}$ & $1.7(0.8-3.5)$ & 0.147 \\
\hline
\end{tabular}

$\mathrm{OR}$, odd ratio; $\mathrm{Cl}$, confidence interval; DBP, diastolic blood pressure; SBP, systolic blood pressure; HDL-C, high-density lipoprotein cholesterol; LDL-C, low-density lipoprotein cholesterol.

${ }^{*} P<0.05$ was considered significant.

Adiponectin was significantly higher in normal glucose tolerance group than in impaired fasting glucose and type 2 diabetes mellitus groups [27]. Diabetes mellitus was an exclusion criterion in our study. Even though, $5 \%$ of total volunteers (9/172 persons) were presented with impair glucose tolerance (IGT) state. There were four persons in the G1 group and five persons in the G2 group with FPG values of $100-107 \mathrm{mg} / \mathrm{dL}$ (The cutoff for IGT was defined as FPG $=100-125 \mathrm{mg} / \mathrm{dL}$, according to current American Diabetes Association (ADA) criteria [28]). Similar results as shown in Table 1 were found after nine persons with IGT were excluded. Serum adiponectin was still higher in the mildly decreased eGFR group $(7.35 \pm 3.35 \mu \mathrm{g} / \mathrm{mL})$ than the normal eGFR group $(6.54 \pm 3.19 \mu \mathrm{g} / \mathrm{mL})$ with statistical significance at $P<0.05$.

Previous reports have shown that obese individuals have lower serum adiponectin than normal weight $[29,30]$. 
Similarly, our study showed that serum adiponectin levels were lower in obesity than normal weight individuals. In addition, low levels of serum adiponectin increase risks of CKD in the obese [3]. Obesity causes marked structural changes in kidneys, leading to loss of nephron function, increases in arterial pressure, and severe renal injury [31]. Furthermore, we observed that serum adiponectin was higher in females than males. Similar findings were shown by Eglit et al. [32], Cnop et al. [33], and Nishizawa et al. [34] that serum adiponectin concentrations were higher in females than in males. This can be explained that males have higher testosterone levels and the hormone suppresses the secretion of adiponectin [33, 34].

Moreover, our results indicated that serum adiponectin levels were positively correlated with age, and HDL-cholesterol, but negatively correlated with weight, BMI, eGFR, triglyceride, and waist and hip circumferences (Table 2). These findings are consistent with the previous studies in healthy, obesity, type- 2 diabetes, CKD, and end-stage kidney disease subjects, showing that serum adiponectin was negatively related with BMI, weight, triglyceride, eGFR, and waist and hip circumferences $[12,14,35,36]$ and positively related with age [37] and HDL-cholesterol [5, 38].

We also found that serum adiponectin depended on age, HDL-cholesterol, and LDL-cholesterol (Table 3). The univariate analysis found that serum adiponectin was correlated with mildly decreased eGFR (Table 4). However, after adjustment for gender, age, and blood pressure, the associations between serum adiponectin and mildly decreased eGFR did not reach statistical significance. Therefore, serum adiponectin was not considered an independent risk factor for mildly kidney damage. Multivariate regression analysis showed that only age was significantly correlated with the mildly decreased eGFR. Hypertension is defined by SBP $\geq 130 \mathrm{mmHg}$ and/or DBP $\geq 85 \mathrm{mmHg}$, and the present study revealed that $30.5 \%$ and $35.4 \%$ of individuals with mildly kidney damage had SBP $\geq$ $130 \mathrm{mmHg}$ and DBP $\geq 85 \mathrm{mmHg}$, respectively. Hypertension is not only a cause but also a consequence of CKD [39, 40]. Therefore, hypertension might be the main cause of mildly decreased eGFR in this study.

ROC curve analysis of serum adiponectin for classifying a mildly decreased eGFR from a normal eGFR showed 70.7\% specificity and $50 \%$ sensitivity when using $5.70 \mu \mathrm{g} / \mathrm{mL}$ as a cutoff value. The area under the ROC curve was 0.652 (95\% CI: $0.570-0.733, P=0.001)$. It is known that serum adiponectin decreases in diseases, such as obesity, diabetes mellitus, and cardiovascular diseases [4-10]; however, increases in adiponectin in blood circulation are found in kidney damage or CKD. Therefore, it is possible that serum adiponectin levels can be useful as a follow-up biomarker to predict the CKD progression.

\section{Conclusion}

Serum adiponectin significantly increased in individuals with mildly decreased eGFR. These findings suggested that increases in serum adiponectin reflected the reduction of kidney functions. In addition, univariate and multivariate analyses implied that serum adiponectin may be a modulating factor, but is not an independent risk factor for mildly kidney damage.

Author contributions. All the authors contributed substantially to the conception and design of this study and to the acquisition of data. AM and PS analyzed, interpreted the data, and drafted the manuscript. All the authors contributed substantially to its critical revision, approved the final version submitted for publication, and take responsibility for the statements made in the published article.

Acknowledgments. Our appreciation is extended to the participants in this study. This research was financially supported by Faculty of Allied Health Sciences, Thammasat University.

Conflict of interest statement. The authors have completed and submitted the International Committee of Medical Journal Editors Uniform Disclosure Form for Potential Conflicts of Interest. None of the authors disclose any conflict of interest.

\section{References}

[1] Diez JJ, Iglesias P. The role of the novel adipocyte-derived hormone adiponectin in human disease. Eur J Endocrinol. 2003; 148:293-300.

[2] Kim HY, Bae EH, Ma SK, Chae DW, Choi KH, Kim Y-S, et al. Association of serum adiponectin level with albuminuria in chronic kidney disease patients. Clin Exp Nephrol. 2016; 20:443-9.

[3] Sweiss N, Sharma K. Adiponectin effects on the kidney. Best Pract Res Clin Endocrinol Metab. 2014; 28:71-9.

[4] Tungtrongchitr R, Sricharoen P, Pongpaew P, Phonrat B, Arthan D, Vudhivai N, et al. Adiponectin/ACP30, a collagen-like plasma protein in relation to anthropometric measurement in Thai overweight and obese subjects. Int J Food Sci Nutr. 2005; 56:193-201.

[5] Yang WS, Lee WJ, Funahashi T, Tanaka S, Matsuzawa Y, Chao CL, et al. Plasma adiponectin levels in overweight and obese Asians. Obesity. 2002; 10:1104-10.

[6] Nigro E, Scudiero O, Monaco ML, Palmieri A, Mazzarella G, Costagliola $C$, et al. New insight into adiponectin role in obesity and obesity-related diseases. Biomed Res Int. 2014; 2014:1-14.

[7] Aleidi S, Issa A, Bustanji H, Khalil M, Bustanji Y. Adiponectin serum levels correlate with insulin resistance in type 2 diabetic patients. Saudi Pharm J. 2015; 23:250-6.

[8] Blaslov K, Bulum T, Zibar K, Duvnjak L. Relationship between adiponectin level, insulin sensitivity, and metabolic syndrome in type 1 diabetic patients. Int J Endocrinol. 2013; 2013:1-6. 
[9] Shibata R, Ouchi N, Murohara T. Adiponectin and cardiovascular disease. Circ J. 2009; 73:608-14.

[10] Siasos G, Tousoulis D, Kollia C, Oikonomou E, Siasou Z, Stefanadis C, et al. Adiponectin and cardiovascular disease: mechanisms and new therapeutic approaches. Curr Med Chem. 2012; 19:1193-209.

[11] Menon V, Li L, Wang X, Greene T, Balakrishnan V, Madero M, et al. Adiponectin and mortality in patients with chronic kidney disease. J Am Soc Nephrol. 2006; 17:2599-606.

[12] Kamimura MA, Canziani MEF, Sanches FR, Velludo CM, Carrero JJ, Bazanelli AP, et al. Variations in adiponectin levels in patients with chronic kidney disease: a prospective study of 12 months. J Bras Nefrol. 2012; 34:259-65.

[13] Saginova E, Galliamov M, Severova M, Surkova O, Fomin V, Ermakov N, et al. The role of leptin, adiponectin and insulinresistance markers in development of early stages of chronic kidney disease and atherosclerosis of carotid arteries in obese patients. Ter Arkh. 2011; 83:47-53.

[14] Sedighi O, Abediankenari S. Relationship between plasma adiponectin level with inflammatory and metabolic markers in patients with chronic kidney disease. Nephrourol Mon. 2014; 6:1-4.

[15] Shen YY, Charlesworth JA, Kelly JJ, Loi KW, Peake PW. Up-regulation of adiponectin, its isoforms and receptors in end-stage kidney disease. Nephrol Dial Transplant. 2006; 22:171-8.

[16] James MT, Hemmelgarn BR, Tonelli M. Early recognition and prevention of chronic kidney disease. Lancet. 2010; 375:1296-309.

[17] Decreased G. Definition and classification of CKD. Kidney Int. 2013; 3:19-62.

[18] Levey AS, Eckardt K-U, Tsukamoto Y, Levin A, Coresh J, Rossert J, et al. Definition and classification of chronic kidney disease: a position statement from kidney disease: Improving Global Outcomes (KDIGO). Kidney Int. 2005; 67:2089-100.

[19] Levey AS, Becker C, Inker LA. Glomerular filtration rate and albuminuria for detection and staging of acute and chronic kidney disease in adults: a systematic review. JAMA. 2015; 313:837-46.

[20] Inker LA, Astor BC, Fox CH, Isakova T, Lash JP, Peralta CA, et al. KDOQI US commentary on the 2012 KDIGO clinical practice guideline for the evaluation and management of CKD. Am J Kidney Dis. 2014; 63:713-35.

[21] Collins AJ, Foley RN, Gilbertson DT, Chen S-C. The state of chronic kidney disease, ESRD, and morbidity and mortality in the first year of dialysis. Clin J Am Soc Nephrol. 2009; 4:5-11.

[22] Kidney Disease: Improving Global Outcomes (KDIGO). KDIGO 2012 Clinical Practice Guideline for the evaluation and management of chronic kidney disease. Kidney Int. 2013; 3(Suppl):1-150.

[23] Levey AS, Stevens LA, Schmid CH, Zhang YL, Castro AF, Feldman $\mathrm{HI}$, et al. A new equation to estimate glomerular filtration rate. Ann Intern Med. 2009; 150:604-12.

[24] Inker LA, Schmid CH, Tighiouart H, Eckfeldt JH, Feldman HI, Greene T, et al. Estimating glomerular filtration rate from serum creatinine and cystatin C. N Engl J Med. 2012; 367:20-9.
[25] World Health Organization. Obesity: preventing and managing the global epidemic: report of a WHO consultation. World Health Organ Tech Rep Ser. 2000; 894:1-253.

[26] Perri A, Vizza D, Lofaro D, Gigliotti P, Leone F, Brunelli E, et al. Adiponectin is expressed and secreted by renal tubular epithelial cells. J Nephrol. 2013; 26:1049-54.

[27] Wolfson N, Gavish D, Matas Z, Boaz M, Shargorodsky M. Relation of adiponectin to glucose tolerance status, adiposity, and cardiovascular risk factor load. Exp Diabetes Res. 2012; 2012:1-5.

[28] Genuth S, Alberti KG, Bennett P, Buse J, Defronzo R, Kahn R, et al. Follow-up report on the diagnosis of diabetes mellitus. Diabetes Care. 2003; 26:3160-7.

[29] Briffa JF, McAinch AJ, Poronnik P, Hryciw DH. Adipokines as a link between obesity and chronic kidney disease. Am J Physiol Renal Physiol. 2013; 305:1629-36.

[30] Ix JH, Sharma K. Mechanisms linking obesity, chronic kidney disease, and fatty liver disease: the roles of fetuin-A, adiponectin, and AMPK. J Am Soc Nephrol. 2010; 21:406-12.

[31] Hall JE. The kidney, hypertension, and obesity. Hypertension. 2003; 41:625-33.

[32] Eglit T, Lember M, Ringmets I, Rajasalu T. Gender differences in serum high-molecular-weight adiponectin levels in metabolic syndrome. Eur J Endocrinol. 2013; 168:385-91.

[33] Cnop M, Havel P, Utzschneider K, Carr D, Sinha M, Boyko E, et al. Relationship of adiponectin to body fat distribution, insulin sensitivity and plasma lipoproteins: evidence for independent roles of age and sex. Diabetologia. 2003; 46:459-69.

[34] Nishizawa H, Shimomura I, Kishida K, Maeda N, Kuriyama H, Nagaretani $\mathrm{H}$, et al. Androgens decrease plasma adiponectin, an insulin-sensitizing adipocyte-derived protein. Diabetes. 2002; 51:2734-41.

[35] Mamaghani F, Zarghami N, Maleki M, Pourhassan MM, Hosseinpanah F. Variation of adiponectin levels in normal and obese subjects: possible correlation with lipid profiles. Int J Endocrinal Metab. 2009; 3:170-8.

[36] Shoji T, Shinohara K, Hatsuda S, Kimoto E, Fukumoto S, Emoto M, et al. Altered relationship between body fat and plasma adiponectin in end-stage renal disease. Metab Clin Exp. 2005; 54:330-4.

[37] Obata Y, Yamada Y, Takahi Y, Baden MY, Saisho K, Tamba S, et al. Relationship between serum adiponectin levels and age in healthy subjects and patients with type 2 diabetes. Clin Endocrinol. 2013; 79:204-10.

[38] Christou GA, Tellis K, Elisaf M, Tselepis AD, Kiortsis DN. High density lipoprotein is positively correlated with the changes in circulating total adiponectin and high molecular weight adiponectin during dietary and fenofibrate treatment. Hormones. 2012; 11:178.

[39] Tedla F, Brar A, Browne R, Brown C. Hypertension in chronic kidney disease: navigating the evidence. Int J Hypertens. 2011; 2011:1-9.

[40] Monhart V. Hypertension and chronic kidney diseases. Cor Vasa. 2013; 55:397-402. 